torate in political science from Yale in 1958. He taught at the University of Michigan from 1958 to 1974, serving as chairman of the political science department in 1970-71 and as dean of the graduate school from 1971 to 1974. He also taught as an associate member at Nuffield College, Oxford, and as a visiting professor at the University of the West Indies and the Australian National University.

Stokes served as vice president of the American Political Science Association and was a recipient of the Association's Woodrow Wilson Foundation Award. He was a fellow of the American Academy of Arts and Sciences, the National Academy of Public Administration, and the American Association for the Advancement of Science, and a former Guggenheim fellow.

Stokes is survived by his wife, Sybil; two daughters, Elizabeth Stokes and Susan Stokes; a sister, Eleanor Stokes Szanton; and three grandchildren. Both Sybil and Susan are political scientists and members of the American Political Science Association. What follows are two appreciations by colleagues who worked with and admired Don Stokes over his long and storied career.

\section{Donald Stokes and the Study of Electoral Politics}

For me, there will always be two distinct sides to Don Stokes. One is the courtly, magisterial "Dean Don" who led Princeton's Woodrow Wilson School for eighteen years, who was instrumental in bringing me to Princeton in 1991, and whose "decanal style verged on the regal" (as Anthony King aptly put it) even after he stepped down from the deanship in 1992.

The other Don Stokes is one I never really knew personally, though I held him in equally high regard. $\mathrm{He}$ is the "early Stokes" who, in a mere dozen years following his arrival at the University of Michigan in 1958, coauthored three classic books that laid the groundwork for everything that has followed in the scholarly study of electoral politics. Having reached the pinnacle of his scholarly field within that brief period, Stokes by 1970 was turning his attention to academic administration and institution-building, first at Michigan and then at Princeton.

Stokes's scholarly career began with a bang when, only two years after arriving in Michigan, he appeared as coauthor with his Survey Research Center colleagues, Angus Campbell, Philip Converse, and Warren Miller, of The American Voter. This book the single most important publication in the entire history of voting research, and the primary source of the ideas, problems, and data that have propelled most of the subsequent development of the field. The American Voter portrayed an electorate whose orientations toward politics were strongly shaped by party loyalties developed early in life, whose familiarity with and attachment to abstract ideologies and policy agendas was remarkably limited, and whose votes in specific elections reflected the overlaying of short-term forcesmost notably, in the 1950 s, the personal popularity of Dwight Eisenhower-on top of more persistent partisan alignments reflecting the social cleavages of the New Deal or even of the Civil War era.

Every major element of this portrait of the American voter has been subjected in the subsequent 37 years to energetic criticism and painstaking reevaluation using new data, theories, and research methods. By the standards of empirical social science, The American Voter has proven to be a work of unsurpassed influence and staying power.

It is difficult to disentangle Stokes's specific contributions to the remarkable collaborative effort that produced The American Voter. However, his distinctive interests and skills emerged more clearly in his subsequent publications, several of which were reprinted among the essays by the same team collected in Elections and the Political Order. If The American Voter was a scholarly symphony, Elections and the Political Order was chamber music of the finest sort, with a stimulating mixture of solo turns and duets within the flexible framework of the larger ensemble. Stokes's contributions to the mix fell into three categories: his brief but important essay on "Spatial Models of Party Competition," his classic articles with Warren Miller on congressional representation, and two pieces of the several he would eventually produce using aggregatelevel data and simple mathematical models to explore the broad historical dynamics of electoral systems.

"Spatial Models of Party Competition" seems to have been one of Stokes's own favorite works; indeed, it is the only one of his writings on electoral politics that he returned to long after it was originally written (in chapters for Dennis Kavanagh's 1992 volume on Electoral Politics and, with his colleague John Dilulio, for Michael Nelson's 1993 volume on The 1992 Elections). The essay is, in the first instance, a penetrating appreciation and critique of Anthony Downs's An Economic Theory of Democracy, tracing the antecedents of Downs's theory in the work of Hotelling and Smithies, noting in passing the similarity between Downs's framework and the framework developed by Duncan MacRae for analyzing roll call votes (a similarity exploited in much subsequent work by Poole and Rosenthal and others), and emphasizing the real limitations of Downs's axioms of unidimensionality, fixed structure, and common reference. Stokes's comments on "the interchange between theory-building and empirical observation" gracefully staked out a sensible middle ground in what has since come to be thought of as a conflict between formal theories of politics on one hand and empirical studies of political behavior on the other.

However, the most enduring positive contribution of "Spatial Models of Party Competition"-and the point Stokes himself was drawn to revisit-was the distinction between "position issues" of the sort encompassed by Downs's theory and the "valence issues" that actually seemed to "have held the center of the stage" in American political history, from the economic panics of the 19 th century to the issues of Korea, communism, and corruption in 1952. Such "valence issues," in Stokes's parlance, "involve the linking of the parties with some condition that is positively or negatively valued by the electorate" as a whole, rather than the positioning of the parties on a dimension along which voters' own 
preferred positions differ. Stokes anticipated the work of Key and Fiorina in noting that valence politics could turn either upon "past or present" (what we would now call "retrospective") conditions or upon "future or potential" (what we would now call "prospective") conditions. Stokes's examples of valence issues include two that have become staples of subsequent electoral analysis: economic prosperity and "Madison Avenue technique and the art of image-building." In both cases, his insistence on the electoral significance of valence issues seems handsomely justified by subsequent scholarship.

Despite the evident importance of valence issues in electoral politics, Stokes's own treatment and terminology have often been acknowledged only in passing, or not at all, by those who followed in his footsteps. The same could hardly be said of his work with Warren Miller on congressional representation, which has been the acknowledged starting point for almost every subsequent scholarly investigation of political representation. The research reported in their 1963 article on "Constituency Influence in Congress" represented the first really significant attempt to break out of the confines of survey-based voting studies in order to connect the behavior of voters with the broader operation of the political system. It necessitated a significant alteration of the sampling frame employed in previous Michigan surveys (to interview voters in a sample of 116 congressional districts, rather than in the nation as a whole), and an ambitious parallel survey of members of Congress and congressional candidates (to examine not only their own political views, but also their perceptions of their constituents' opinions).

As pioneering scholarship goes, it was a remarkably rich and polished effort. Miller and Stokes developed an elegant model of the empirical connections they observed among constituents' attitudes, representatives' attitudes, representatives' perceptions of constituents' attitudes, and roll call votes-and grounded that model firmly in the classic normative literature on representation as well as in previous empirical scholarship. At the same time, they did not fail to notice a single vivid, politically significant tree in their forest of correlation coefficients: the ouster of Representative Brooks Hays, a prominent moderate on civil rights issues, in a conservative Arkansas district in which every one of the 13 voters in their sample (as against 24 percent in other districts) had read or heard something about both Hays and his successful write-in challenger.

As with The American Voter, subsequent scholars who have criticized or even superseded various aspects of Miller and Stokes's work on representation have often failed to notice how innovative and ambitious their project was in its time, or how profoundly it has continued to shape the thinking and research even of those who aspire to revise or overthrow it. In that sense, as in others, both works are true classics.

The third, and perhaps the least appreciated, of Stokes's contributions to Elections and the Political Order consisted of two articles on "Party Loyalty and the Likelihood of Deviating Elections" and (with Gudmund Iversen) "On the Existence of Forces Restoring Party Competition." Both these pieces employed mathematical models - the former a normal error model and the latter a random walk model-to capture important aspects of long-run electoral dynamics. If election outcomes reflect a combination of long-term partisan divisions and short-term forces, Stokes asked, how frequently should we expect the "minority" party to win? And in the longer term, how likely is it that a given era's "minority" party will be able to regain electoral parity? "In voting research, as any branch of inquiry," Stokes wrote, "knowledge is advanced as much by seeing new problems as by solving old ones." His deceptively simple questions, while derived from the central findings of survey-based voting studies, raised important new problems for our understanding of political history and of "elections as total social or political events."

These two articles, along with Stokes's subsequent pieces on "A Variance Components Model of Political Effects" (in John Claunch's Mathematical Applications in Politi- cal Science), "Parties and the Nationalization of Electoral Forces" (in William Nisbet Chambers and Walter Dean Burnham's The American Party Systems) and "Cross-Level Inference as a Game Against Nature" (in Joseph Bernd's Mathematical Applications in Political Science IV), present a picture of a perceptive, imaginative, and ambitious scholar struggling to invent or adapt the analytical techniques he needed to expand further the horizon of his field. Taking as a starting point the central findings of The American Voter on party identification, short term forces, and the nature of electoral competition, he aimed both to extend those findings in time and space and to plumb their implications for the broader political system. While survey data could be mined with great skill in The American Voter to reveal the contemporary traces of a few decades of political change, or in "Constituency Influence in Congress" to outline the nature of the relationship between voters and their representatives, Stokes's historical vision was even longer and his substantive reach was even broader.

To achieve his aims, Stokes would have to distill the essence of electoral dynamics not from richly detailed sample surveys, but from the aggregated election returns that constitute most of our available data about voting behavior outside of the contemporary American setting. To do so today, using the sophisticated methods for time-series analysis and cross-level inference developed by econometricians, statisticians, and political methodologists in the intervening thirty years, would be a masterful achievement. To do so using the tools of the 1960 s was a feat even Stokes could only partially accomplish. Partial though it was, the accomplishment represents one of his greatest scholarly achievements.

Of these pieces, the most complete-indeed, nearly perfect-was "Parties and the Nationalization of Electoral Forces," in which Stokes used congressional election returns covering nine decades, plus comparable data from Britain, to document historical changes and systemic differences in the relative importance of national and local factors in elec- 
toral turnout and voting behavior. Here are the evolution of party systems, the profound impact of presidential as against parliamentary institutions, the electoral basis for responsible party government, the rise of the modern mass media, and the "vanishing marginals" of subsequent congressional election scholarship, all encompassed in twenty highly readable pages with nine tables and figures. One would be hard pressed to find a more impressive display of originality, erudition, and analytic resourcefulness in the whole literature of voting studies.

Stokes's last great work of electoral scholarship, written in collaboration with David Butler, was Political Change in Britain. In many ways this book harked back to The American Voter, embracing more completely than in any of the Michigan school's other international collaborations the model of a comprehensive, survey-based analysis of national voting behavior in a particular political era. The analytical framework of The American Voter was elaborated in Political Change in Britain to distinguish more explicitly among generational changes in the composition of the electorate, fundamental shifts in partisan loyalties, and the effects of candidates, campaigns, and valence issues in specific elections. The fundamental findings of the earlier book regarding the limits of issue awareness and ideological competition, the structuring role of parties, and the interplay of long-term and short-term forces were reiterated and extended. At the same time, the distinctive features of the British electoral system-the prominent role of social class and trade unions, the impact of a nationalized, partisan press, and the distinctive interplay of national and local forces in a parliamentary system-received prominent attention both in their own right and for the light they shed on broader theoretical questions of cross-national interest. Finally, Butler and Stokes exploited their panel survey design to provide a more direct analysis of political dynamics than in The American Voter, approaching a synthesis of the historical and systemic perspective of Campbell, Key, and Stokes himself on one hand and the campaign-specific analyses of the Columbia school and the Nuffield studies on the other. It was a bravura performance, unmatched in the subsequent cumulation of electoral research, and a fitting capstone to the first phase of Stokes's remarkable professional life.

\section{Larry M. Bartels \\ Princeton University}

\section{Donald Stokes at Princeton}

Donald Stokes joined Princeton's faculty in 1974 as Professor of Politics and Public Affairs and as Dean of the Woodrow Wilson School. Five years later he was named to the Class of 1943 University Professorship. He served as Dean for 18 years, before stepping down in 1992 to return to full-time teaching and scholarship.

Stokes guided the Woodrow Wilson School through a remarkable period of growth and diversification. The School grew from a faculty of 26 , most of them in economics and political science, to a faculty of 51 , with added specialists in geography, demography, sociology, urban planning, and science policy.

Central to this expansion was Stokes's creative management of the School's budget in the mid-1970s that allowed expenses to lag behind the growth of income from the Robertson endowment (which supports the School's graduate program). This one change built a financial cushion for the School that allowed the investment advisors for the Robertson Foundation to manage the endowment very aggressively and all this just as the stock market began its own remarkable period of growth. Stokes was also a tireless fund raiser, increasing the number of endowed chairs at the School from four to thirteen, creating four endowed preceptorships for assistant professors, and raising money for graduate fellowships, research, and building expansion.

Stokes also championed curricular innovations. At the undergraduate level, he continued the School's reliance on policy conferences and policy task forces, where students work in teams to develop solutions to important policy problems; but he also stimulated the creation of a rich array of undergraduate courses, including those on the mass media, the American city, quantitative analysis, ethics and public policy, geography and public affairs, science and technology, and organization and management. The master's program in public affairs added new courses in public management, demography, science policy, and urban planning. The Ph.D. program transformed itself from a tiny program for a few graduates of the School's own M.P.A. program into a residential Ph.D. program which could admit students from anywhere.

Stokes was an active teacher, both while he was Dean and during the subsequent five years. But he never once taught his "Michigan courses" on voting behavior or research methodology (except to run a few preceptorials in Michael Kagay's undergraduate course on public opinion). Instead he immersed himself in new forms of teaching, including interdisciplinary teaching on science policy, organizations, and management. As an administrator, he championed the creation of a required course for first-year M.P.A students on political and organizational analysis. Then, when he found it difficult to draft a sufficient number of his political science colleagues to teach the course, he volunteered and co-taught it for twelve of the last thirteen years.

He was also an institution builder. Stokes helped two of the Schools research programs grow and prosper the Office of Population Research and the Center of International Studies and he created a new Center of Domestic and Comparative Policy Studies and a small Program for New Jersey Affairs. He was an active member of the Department of Politics, where he played a major role in personnel decisions; by his actions it was clear that he cared equally for faculty jointly appointed with the School and those with Departmentonly appointments. He was endlessly supportive and a pleasure to work with. He believed that the School could not thrive unless the Departments of Politics and Economics prospered, and he used the School's resources to help insure that both became stronger.

Stokes's efforts at the Woodrow 